\title{
BEHAVIOR OF STRIP FOOTING ON REINFORCED SAND SLOPE
}

\author{
Enas B. ALTALHEa, Mohd Raihan TAHA ${ }^{\mathrm{a}}$, Fathi M. ABDRABBO ${ }^{\mathrm{b}}$ \\ ${ }^{a}$ Department of Civil and Structural Engineering, Universiti Kebangsaan Malaysia, 43600 UKM Bangi, \\ Selangor, Malaysia \\ ${ }^{b}$ Department of Civil Engineering, University of Alexandria, 21 Riad Street, Zizinia, Alexandria, Egypt
}

Received 24 May 2012; accepted 11 Dec 2012

\begin{abstract}
This study evaluated the effects of single, double, and triple reinforcing layers on the bearing capacity ratio (BCR) of strip footing on a sand slope system. Seventy-two laboratory-loading tests were conducted on a stripfooting model on a reinforced sand slope. Moreover, this study illustrated the effects of the different parameters of two reinforcing layers on the bearing capacity of a double-reinforced sand slope. The BCR increased from 1.06 to 3.00 for single-reinforced slope soils, 1.09 to 7.73 for double-reinforced slope soils, and up to 8.00 for three-layered reinforced systems. For double-reinforced soil slopes, the most effective spacing between the two reinforcing layers is $0.3 \mathrm{~B}$.
\end{abstract}

Keywords: strip footing, geotextile reinforcement, sand slope, bearing capacity.

\section{Introduction}

The reinforced steep slope has been successfully applied to various applications such as road broadening and failed slope repair. An understanding of the behavior of reinforced slopes loaded with surface footings is of practical importance to geotechnical engineers. Although several works on reinforced flat grounds exist (Fragaszy, Lawton 1984; Milligan et al. 1986; Mittal et al. 2009), investigations of footings on reinforced slopes are rather limited (Selvadurai, Gnanendran 1989; Manjunath, Dewaikar 1994; Huang et al. 1994; Lee, Manjunath 2000; Jahanandish, Keshavarz 2005; El Sawwaf 2005).

Slope reinforcement is a cost-effective method for improving the ultimate bearing capacity of a footing on a slope and for decreasing the settlement values to accepted limits (Dash et al. 2003; Boushehrian, Hataf 2003; Patra et al. 2005, 2006). Both the ultimate bearing capacity and the settlement characteristics of the foundation can be improved by the inclusion of reinforcements in the soil, that is, using multiple layers of geogrids at different depths and widths under the footing. These reinforcements resist the accumulated horizontal shear stress in the soil mass under the footing and transfer them to the adjacent stable layers of the soil, thereby improving the vertical behavior of the footing.

However, few studies have focused on the behavior of shallow footing on reinforced sand. El Sawwaf (2007) and El Sawwaf and Nazir (2010) studied the ultimate bearing capacity and settlement of a rectangular model footing as well as a strip foundation on geogrid-reinforced sand subjected to the sum of a static load. Moghaddas Tafreshi and Dawson (2010) investigated the behavior of strip footings on 3D and planar geotextile-reinforced sand beds subjected to repeated loads.

Yoo (2001) investigated the bearing capacity of strip footing on a geogrid-reinforced soil slope using laboratory model tests. The author showed that for single-layer reinforced sand, the optimum embedment depth for the first reinforcement layer, wherein the bearing capacity is highest, is between 0.3 and 0.7 of the footing width. For multilayer reinforced sand, the optimum depth ratio for the upper layer is $0.3 \mathrm{~B}$ and the optimum vertical spacing between layers is between 0.5 and $0.8 \mathrm{~B}$. The best number of reinforced layers with the highest bearing capacity ratio (BCR) is three layers. Moreover, reinforcing layers are only effective within $1.5 \mathrm{~B}$ from the edge of the slope.

El Sawwaf and Nazir (2011) studied the behavior of strip-footing models on geosynthetic-reinforced sand slope subjected to both monotonic and cyclic loads. The effects of the partial replacement of a compacted sand layer and the inclusion of geosynthetic reinforcement were also investigated. The inclusion of soil reinforcement in the replaced sand not only increases the stability of the sandy slope significantly but also decreases both the monotonic and the cumulative cyclic settlements considerably, leading to an economic design of the footings. However, the efficiency of sand-geogrid systems depends on the properties of the cyclic load and the location of the footing relative to the slope crest.

Corresponding author: Enas B. Altalhe

E-mail: enasraft@yahoo.com 
Alamshahi and Hataf (2009) conducted a series of numerical and model tests to evaluate the bearing capacity of strip footings on sand slopes reinforced with a geogrid and grid anchor. Their study emphasized the effects of geogrid and grid-anchor reinforcements and their locations on the bearing capacity and settlement characteristics of strip footings.

Choudhary et al. (2010) conducted a series of model footing tests on the bearing capacity behavior of a strip footing on top of a geogrid-reinforced fly ash slope. This study covered a wide range of boundary conditions, including unreinforced cases with varying parameters such as location and depth of single geogrid-layer embedments, number of geogrid layers, footing location relative to the slope crest, slope angles, and footing width. Both the pressure-settlement behavior and the ultimate bearing capacity of a footing on top of a fly ash slope can be enhanced using reinforcing layers. The efficiency of a fly ash geogrid system increases with increasing geogrid layers and distance of the footing edge from the slope.

This study investigates the behavior of strip footings on a granular slope with double and triple layers of geotextile reinforcement. Variable parameters include double-layer embedment ratio, relative sand density, and footing location relative to the slope crest.

\section{Laboratory model test}

\subsection{Soil bins and strip-footing model}

The soil bin of the sand and the footing model had inside dimensions of $2.0 \mathrm{~m}$ by $0.6 \mathrm{~m}$ in plan and $0.62 \mathrm{~m}$ in height. The walls of the box were steel plates lined with Mylar plastic sheeting and printed with a square grid pattern, which provided a reference frame for monitoring displacements within the backfill. To prevent scratches and minimize side friction, a second plain Mylar sheet was used as protection. The box was sufficiently rigid to maintain plane strain conditions in the reinforced slope models. The soil bin was mounted on a bigger soil bin filled with sand and supporting a loading frame.

The strip-footing model $(580 \mathrm{~mm}$ long, $50 \mathrm{~mm}$ wide and $15 \mathrm{~mm}$ thick) was made of steel plate with a notch hole at the top center to accommodate a bearing ball. The footing was positioned on the sand bed with the length of the footing running parallel to the full width of the tank to create a plane strain condition within the test set-up. The two ends of the footing plate were polished to minimize the end friction effects. The load was transferred to the footing through the bearing ball. This arrangement produced a hinge, allowing the footing to rotate freely as it approached failure and eliminating any potential moment transfer from the loading fixture. The corresponding settlement was recorded using two vertical dial gauges with an accuracy of $0.01 \mathrm{~mm}$. The two vertical dial gauges were placed on two sides of the strip footing with respect to the loading point to measure the average settlement and detect any differential settlements.

\subsection{Test materials}

\subsubsection{Reinforcements}

Nonwoven geotextile reinforcing material was used in this research. The typical physical and technical properties of the geotextiles were obtained from the data sheet of the manufacturer (Makarm Tex, Cairo, Egypt, Table 1).

\subsubsection{Sand}

The sand used in this study was medium coarse with a grain size of $0.06 \mathrm{~mm}$ to $2.00 \mathrm{~mm}$. The grain size distribution of the sand is shown in Figure 1. The optimum moisture content $(\sim 10 \%)$ was determined by a standard Proctor compaction test. Different relative densities of

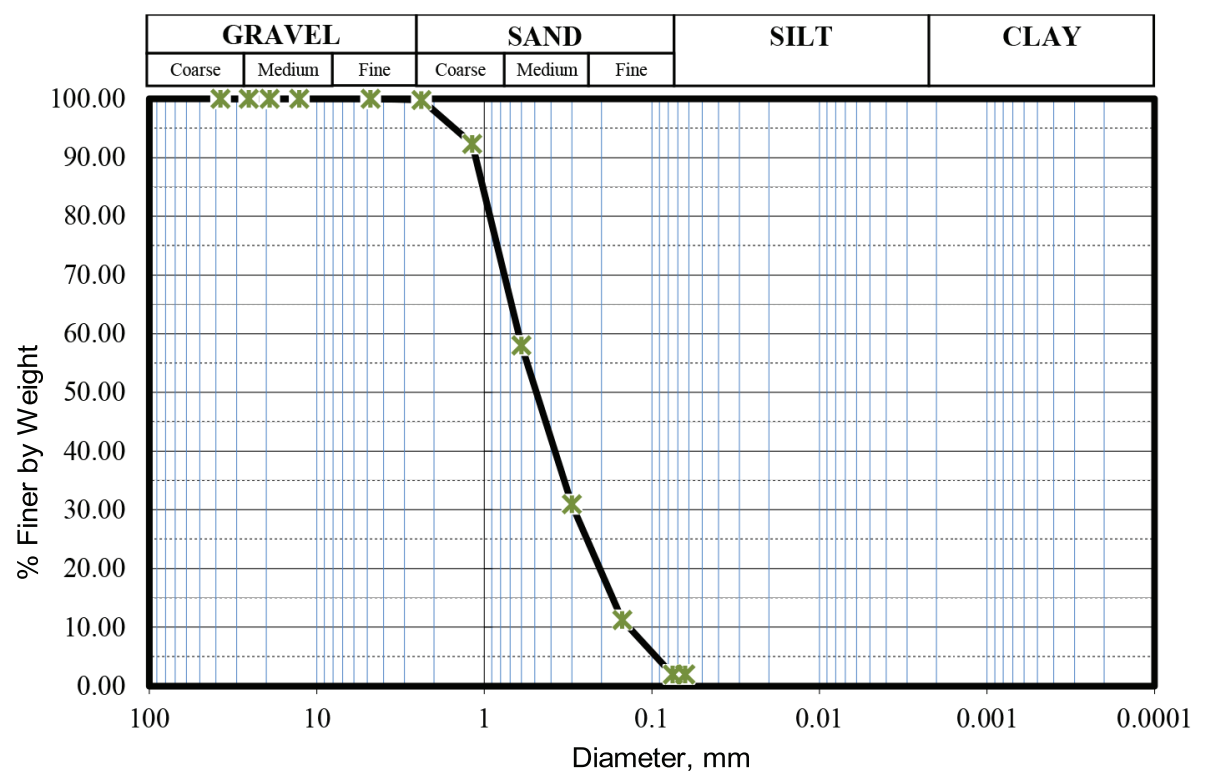

Fig. 1. Grain size distribution of the sand 
Table 1. Engineering properties of the geotextile used in this study

\begin{tabular}{lc}
\hline Parameter & Value/Type \\
\hline Structure & nonwoven geotextile \\
\hline Thickness $(\mathrm{mm})$ & 3.5 \\
\hline Weight $\left(\mathrm{g} / \mathrm{m}^{2}\right)$ & 350 \\
\hline Grab tensile strength, MD $(\mathrm{N})$ & 930 \\
\hline Grab tensile strength, CD $(\mathrm{N})$ & 1,500 \\
\hline Permeability $(\mathrm{cm} / \mathrm{s})$ & 0.25 \\
\hline Transmissivity $(\mathrm{L} / \mathrm{M} / \mathrm{H})$ & 200 \\
\hline
\end{tabular}

Table 2. Characteristics of the sand

\begin{tabular}{lc}
\hline Parameter & Value \\
\hline Uniformity coefficient $(\mathrm{Cu})$ & 4.55 \\
\hline Effective diameter $(\mathrm{mm})$ & 0.14 \\
\hline Maximum dry unit weight $\left(\mathrm{kN} / \mathrm{m}^{3}\right)$ & 18.74 \\
\hline Minimum dry unit weight $\left(\mathrm{kN} / \mathrm{m}^{3}\right)$ & 16.7 \\
\hline Specific gravity $(\mathrm{Gs})$ & 2.64 \\
\hline Residual effective angle of internal friction $\left(\Phi^{\prime}\right)$ & $38^{\circ}$ \\
\hline
\end{tabular}

the sand were obtained by forming the designed weight of the sand into a certain volume of the soil bin by compaction. The properties of this soil are given in Table 2 .

\section{Test program}

The test program primarily consisted of load tests on a strip-footing model $(580 \mathrm{~mm}$ long, $50 \mathrm{~mm}$ wide, and $15 \mathrm{~mm}$ thick) placed on top of a reinforced or unreinforced sand slope. Footing width $(B)$ is always constant $(50 \mathrm{~mm})$. The depth of the first reinforcement layer below the footing base is represented by $d$; the width of the reinforcement layer is $L$; the vertical spacing between the reinforcement layers is $h$; the edge distance of the footing is $X$; the depth of the lower layer is $H_{r}$. The definition of the variables are shown in Figure 2, and the detailed test program is given in Table 3. In each series of tests, three different tests on the reinforcement were conducted with different $\mathrm{h} / \mathrm{B}$. Thus, the total number of tests conducted was 72 .

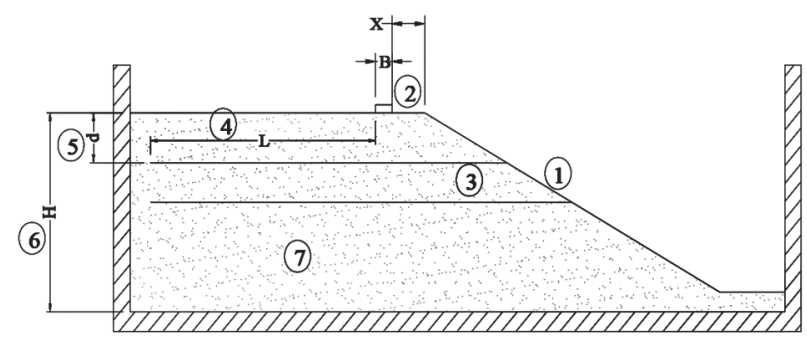

Fig. 2. Geometric parameters of the reinforced sand slope: 1-slope of sand; 2 - footing model; 3 - reinforcing layer; 4 - layer of reinforced a beyond footing end; 5 - depth of reinforced; 6 - depth of sand; 7 - sand

\section{Results and discussion}

Load-settlement (P-S) curves were obtained for the test models. Normalized values were used, that is, normalized stress $(\mathrm{P} / \gamma \mathrm{B})$ vs. settlement ratio $(\mathrm{S} / \mathrm{B})$, where $\mathrm{P}$ is the load $(\mathrm{KN}), \mathrm{S}(\mathrm{mm})$ is the settlement, $\gamma$ is the unit weight of the soil, and B is the footing width. No definite failure point was observed in the P-S curves; thus, the ultimate bearing capacity was determined from the normalized $\mathrm{P}-\mathrm{S}$ curves as the pronounced peaks. Thereafter, the footing collapsed and the load decreased (Fig. 3). A significant increase occurred in the failure load of the model slope with reinforcement compared to that without reinforcement (Fig. 3).

\subsection{Effect of relative density on $B C R$}

The BCR was used and described as $\mathrm{q}_{\mathrm{r}} / \mathrm{q}_{\mathrm{o}}$, where $\mathrm{q}_{\mathrm{r}}$ and $\mathrm{q}_{\mathrm{o}}$ are the ultimate bearing capacities of the footing on reinforced and unreinforced slopes, respectively. The $\mathrm{BCR}$ is the ratio of the ultimate loads attained from the loading test on reinforced sand to those of unreinforced sand with the same relative density.

The $\mathrm{P} / \gamma \mathrm{B}$ versus the $\mathrm{S} / \mathrm{B}$ of the footing on reinforced sand with the same reinforcement length $(\mathrm{L} / \mathrm{B})$ and embedment $(\mathrm{d} / \mathrm{B})$ ratios with different relative densities $\left(D_{r}\right)$ are shown in Figure 4 . The peak load of each test was determined, and the BCR was calculated and plotted against the $\mathrm{D}_{\mathrm{r}}$. The effect of a reinforcing sheet is more visible in soil with lower relative density (Fig. 5). This effect can be attributed to the modulus of deformation of the soil. A higher relative density of soil corresponds to a higher modulus of deformation. For soils with high relative density, the modulus of deformation approaches that of the reinforcing material; thus, the reinforcing may not be highly effective. On the contrary, the modulus of deformation for soils with low relative density is significantly affected by the reinforcing material.

In the case of footing on a reinforced sand slope, large deformations of the footing are required to achieve the beneficial effects of the reinforcement. Moreover, the most effective vertical spacing of the reinforcement layers (i.e. the highest $\mathrm{BCR}$ ) occurs at $\mathrm{h} / \mathrm{B}=0.3$, in which the BCR reaches its peak value irrespective of the $D_{r}$ (Figs 6a-6c). The failure of the soil footing system is dominated by the stability of the slope. However, when $\mathrm{X} / \mathrm{B}$ becomes lower than 1.0, the failure is dominated by the shear planes developed in the soil beneath the footing. At $\mathrm{X} / \mathrm{B}=0$, the most effective vertical spacing between the reinforcing layers is $0.3 \mathrm{~B}$, whereas at $\mathrm{X} / \mathrm{B}>0$, the most effective vertical spacing between the reinforcing layers is greater than 0.3 and approaching 1.0. This observation confirms the results of Adams and Collin (1997).

\subsection{Effect of the number of geotextile layers}

A series of tests was conducted to study the effect of variations in the number of geotextile layers on the slope behavior of strip footing. In these tests, the depth, location, and spacing of the first layer were kept constant 
Table 3. Experimental test program

\begin{tabular}{|c|c|c|}
\hline Series & Constant parameters & Variable parameters \\
\hline 1 & Tests on non-reinforced slope, $\mathrm{X} / \mathrm{B}=0, \mathrm{D}_{\mathrm{r}}=60 \%$ & \\
\hline 2 & $\mathrm{X} / \mathrm{B}=0, \mathrm{~d} / \mathrm{B}=0.5, \mathrm{~N}=2, \mathrm{~L} / \mathrm{B}=6, \mathrm{D}_{\mathrm{r}}=60 \%$ & $\mathrm{~h} / \mathrm{B}=0.3,0.5,1.0$ \\
\hline 3 & $\mathrm{X} / \mathrm{B}=0, \mathrm{~d} / \mathrm{B}=0.5, \mathrm{~N}=3, \mathrm{~L} / \mathrm{B}=6, \mathrm{D}_{\mathrm{r}}=60 \%$ & $\mathrm{~h} / \mathrm{B}=0.3,0.5,1.0$ \\
\hline 4 & Tests on non-reinforced slope, $\mathrm{X} / \mathrm{B}=0, \mathrm{D}_{\mathrm{r}}=70 \%$ & \\
\hline 5 & $\mathrm{X} / \mathrm{B}=0, \mathrm{~d} / \mathrm{B}=0.5, \mathrm{~N}=2, \mathrm{~L} / \mathrm{B}=6, \mathrm{D}_{\mathrm{r}}=70 \%$ & $\mathrm{~h} / \mathrm{B}=0.3,0.5,1.0$ \\
\hline 6 & $\mathrm{X} / \mathrm{B}=0, \mathrm{~d} / \mathrm{B}=0.5, \mathrm{~N}=3, \mathrm{~L} / \mathrm{B}=6, \mathrm{D}_{\mathrm{r}}=70 \%$ & $\mathrm{~h} / \mathrm{B}=0.3,0.5,1.0$ \\
\hline 7 & Tests on non-reinforced slope, $\mathrm{X} / \mathrm{B}=0, \mathrm{D}_{\mathrm{r}}=85 \%$ & \\
\hline 8 & $\mathrm{X} / \mathrm{B}=0, \mathrm{~d} / \mathrm{B}=0.5, \mathrm{~N}=2, \mathrm{~L} / \mathrm{B}=6, \mathrm{D}_{\mathrm{r}}=85 \%$ & $\mathrm{~h} / \mathrm{B}=0.3,0.5,1.0$ \\
\hline 9 & $\mathrm{X} / \mathrm{B}=0, \mathrm{~d} / \mathrm{B}=0.5, \mathrm{~N}=3, \mathrm{~L} / \mathrm{B}=6, \mathrm{D}_{\mathrm{r}}=85 \%$ & $\mathrm{~h} / \mathrm{B}=0.3,0.5,1.0$ \\
\hline 10 & Tests on non-reinforced slope, $\mathrm{X} / \mathrm{B}=1, \mathrm{D}_{\mathrm{r}}=60 \%$ & \\
\hline 11 & $\mathrm{X} / \mathrm{B}=1, \mathrm{~d} / \mathrm{B}=0.5, \mathrm{~N}=2, \mathrm{~L} / \mathrm{B}=6, \mathrm{D}_{\mathrm{r}}=60 \%$ & $\mathrm{~h} / \mathrm{B}=0.3,0.5,1.0$ \\
\hline 12 & $\mathrm{X} / \mathrm{B}=1, \mathrm{~d} / \mathrm{B}=0.5, \mathrm{~N}=3, \mathrm{~L} / \mathrm{B}=6, \mathrm{D}_{\mathrm{r}}=60 \%$ & $\mathrm{~h} / \mathrm{B}=0.3,0.5,1.0$ \\
\hline 13 & Tests on non-reinforced slope, $\mathrm{X} / \mathrm{B}=1, \mathrm{D}_{\mathrm{r}}=70 \%$ & \\
\hline 14 & $\mathrm{X} / \mathrm{B}=1, \mathrm{~d} / \mathrm{B}=0.5, \mathrm{~N}=2, \mathrm{~L} / \mathrm{B}=6, \mathrm{D}_{\mathrm{r}}=70 \%$ & $\mathrm{~h} / \mathrm{B}=0.3,0.5,1.0$ \\
\hline 15 & $\mathrm{X} / \mathrm{B}=1, \mathrm{~d} / \mathrm{B}=0.5, \mathrm{~N}=3, \mathrm{~L} / \mathrm{B}=6, \mathrm{D}_{\mathrm{r}}=70 \%$ & $\mathrm{~h} / \mathrm{B}=0.3,0.5,1.0$ \\
\hline 16 & Tests on non-reinforced slope, $\mathrm{X} / \mathrm{B}=1, \mathrm{D}_{\mathrm{r}}=85 \%$ & \\
\hline 17 & $\mathrm{X} / \mathrm{B}=1, \mathrm{~d} / \mathrm{B}=0.5, \mathrm{~N}=2, \mathrm{~L} / \mathrm{B}=6, \mathrm{D}_{\mathrm{r}}=85 \%$ & $\mathrm{~h} / \mathrm{B}=0.3,0.5,1.0$ \\
\hline 18 & $\mathrm{X} / \mathrm{B}=1, \mathrm{~d} / \mathrm{B}=0.5, \mathrm{~N}=3, \mathrm{~L} / \mathrm{B}=6, \mathrm{D}_{\mathrm{r}}=85 \%$ & $\mathrm{~h} / \mathrm{B}=0.3,0.5,1.0$ \\
\hline 19 & Tests on non-reinforced slope, $\mathrm{X} / \mathrm{B}=2, \mathrm{D}_{\mathrm{r}}=60 \%$ & \\
\hline 20 & $\mathrm{X} / \mathrm{B}=2, \mathrm{~d} / \mathrm{B}=0.5, \mathrm{~N}=2, \mathrm{~L} / \mathrm{B}=6, \mathrm{D}_{\mathrm{r}}=60 \%$ & $\mathrm{~h} / \mathrm{B}=0.3,0.5,1.0$ \\
\hline 21 & $\mathrm{X} / \mathrm{B}=2, \mathrm{~d} / \mathrm{B}=0.5, \mathrm{~N}=3, \mathrm{~L} / \mathrm{B}=6, \mathrm{D}_{\mathrm{r}}=60 \%$ & $\mathrm{~h} / \mathrm{B}=0.3,0.5,1.0$ \\
\hline 22 & Tests on non-reinforced slope, $\mathrm{X} / \mathrm{B}=2, \mathrm{D}_{\mathrm{r}}=70 \%$ & \\
\hline 23 & $\mathrm{X} / \mathrm{B}=2, \mathrm{~d} / \mathrm{B}=0.5, \mathrm{~N}=2, \mathrm{~L} / \mathrm{B}=6, \mathrm{D}_{\mathrm{r}}=70 \%$ & $\mathrm{~h} / \mathrm{B}=0.3,0.5,1.0$ \\
\hline 24 & $\mathrm{X} / \mathrm{B}=2, \mathrm{~d} / \mathrm{B}=0.5, \mathrm{~N}=3, \mathrm{~L} / \mathrm{B}=6, \mathrm{D}_{\mathrm{r}}=70 \%$ & $\mathrm{~h} / \mathrm{B}=0.3,0.5,1.0$ \\
\hline 25 & Tests on non-reinforced slope, $\mathrm{X} / \mathrm{B}=2, \mathrm{D}_{\mathrm{r}}=85 \%$ & \\
\hline 26 & $\mathrm{X} / \mathrm{B}=2, \mathrm{~d} / \mathrm{B}=0.5, \mathrm{~N}=2, \mathrm{~L} / \mathrm{B}=6, \mathrm{D}_{\mathrm{r}}=85 \%$ & $\mathrm{~h} / \mathrm{B}=0.3,0.5,1.0$ \\
\hline 27 & $\mathrm{X} / \mathrm{B}=2, \mathrm{~d} / \mathrm{B}=0.5, \mathrm{~N}=3, \mathrm{~L} / \mathrm{B}=6, \mathrm{D}_{\mathrm{r}}=85 \%$ & $\mathrm{~h} / \mathrm{B}=0.3,0.5,1.0$ \\
\hline
\end{tabular}

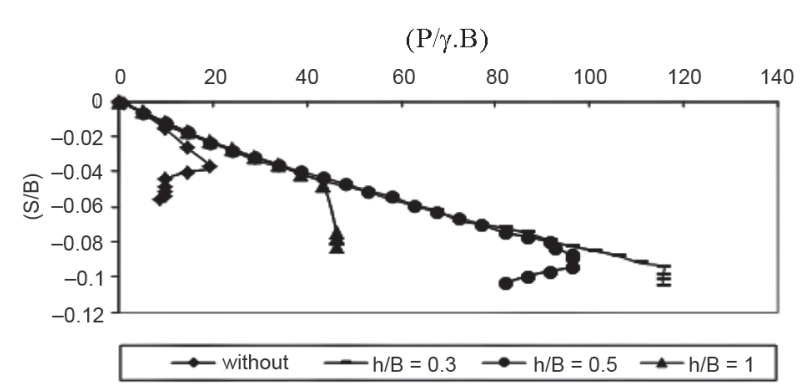

Fig. 3. Variations of $\mathrm{P} / \gamma \mathrm{B}$ with $\mathrm{S} / \mathrm{B}$ for the model slope with different vertical spacings of geotextile $\left(\mathrm{D}_{\mathrm{r}}=60 \%, N=2\right.$, and $X=0$ )

but the number of geotextile layers was varied. A typical response of the $\mathrm{P} / \gamma \mathrm{B}-\mathrm{S} / \mathrm{B}$ plot indicates the effect of the number of geotextile layers on slope behavior (Fig. 7a). Figure $7 \mathrm{a}$ shows the variations of the $\mathrm{P} / \gamma \mathrm{B}$ from the model test against the $\mathrm{S} / \mathrm{B}$ for the strip footing on a sand slope, as well as the footing behavior when placed on sand without reinforcement. For the same settlement, the inclusion of geotextile layers increased the load bearing capacity of the strip footing and considerably decreased

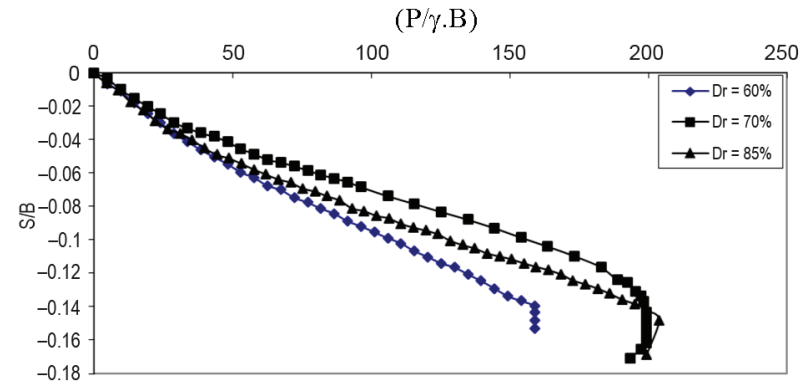

Fig. 4. Variations of $\mathrm{P} / \gamma \mathrm{B}$ with $\mathrm{S} / \mathrm{B}$ for the model slope with different relative soil densities $(N=2 ; \mathrm{X} / \mathrm{B}=2)$

the $\mathrm{S} / \mathrm{B}$ with an increase in the number of geotextile layers (Fig. 7a).

The typical responses of the BCR from the tests against the number of layers for a footing at the slope crest are shown in Figure 7b. For the same settlement, the inclusion of geotextile layers increased the load bearing capacity of the strip footing (Fig. 7b). For the same footing load, the settlement ratio decreased considerably with an increase in the distance of the footing from the 


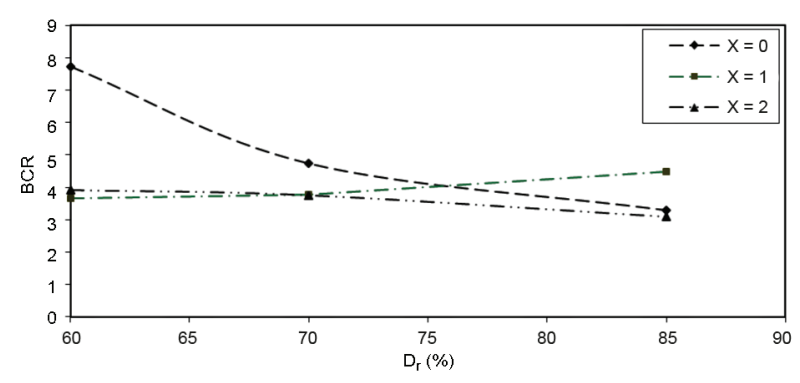

Fig. 5. BCR versus $D_{\mathrm{r}}$ for the number of reinforcement layers $(N=2 ; \mathrm{h} / \mathrm{B}=0.3)$

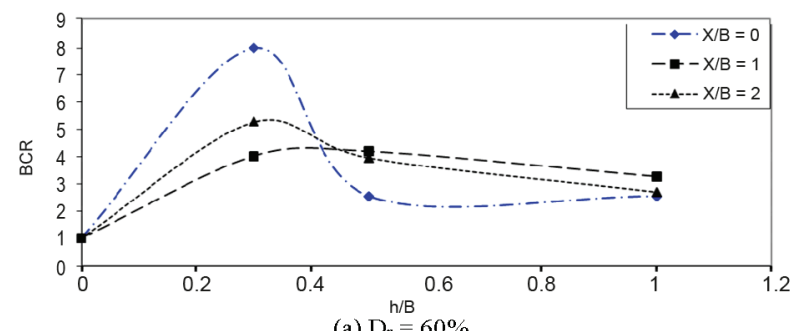

(a) $D_{r}=60 \%$

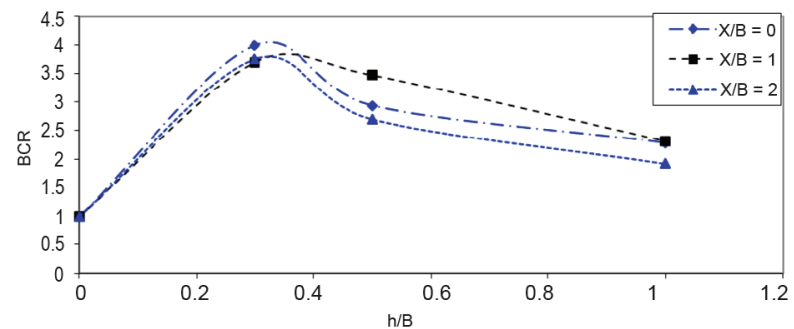

(b) $\mathrm{D}_{\mathrm{r}}=70 \%$

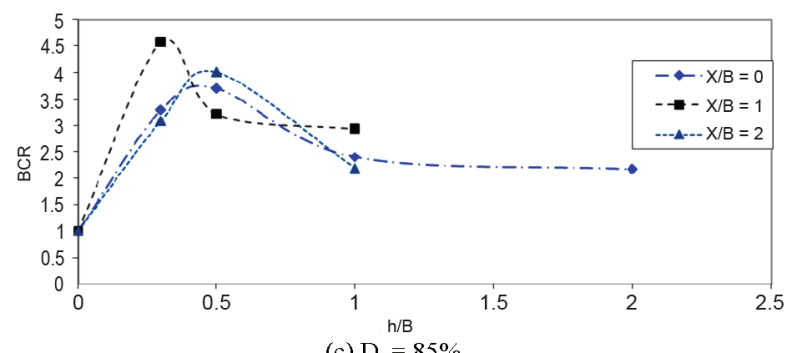

(c) $\mathrm{D}_{\mathrm{r}}=85 \%$

Fig. 6. BCR versus $\mathrm{h} / \mathrm{B}$ for the number of reinforcement layers $n=2$

slope edge and in the number of geotextile layers. This behavior continued until $n=2$. For $n=3$, no increase or reduction was observed in the BCR. Similar behavior was observed by El Sawwaf (2007), Lee and Manjunath (2000), and Alamshahi and Hataf (2009). No tests were conducted using more than three geotextile layers because of the limited depth of the sand fill. However, for certain sand slopes and reinforcement conditions, a critical number of reinforcement layers were provided. Thereafter, the improvement in bearing capacity not only became marginal but also had an opposite effect. This observation is consistent with previous studies of strips or square plates over entirely dry sand (i.e. Omar et al. 1993; Das, Omar 1994; Lee, Manjunath 2000; Yoo 2001; El Sawwaf 2005; Alamshahi, Hataf 2009).

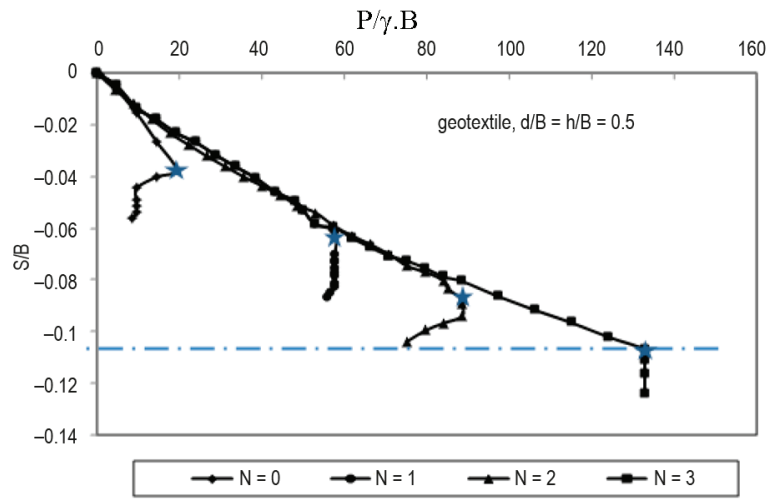

(a)

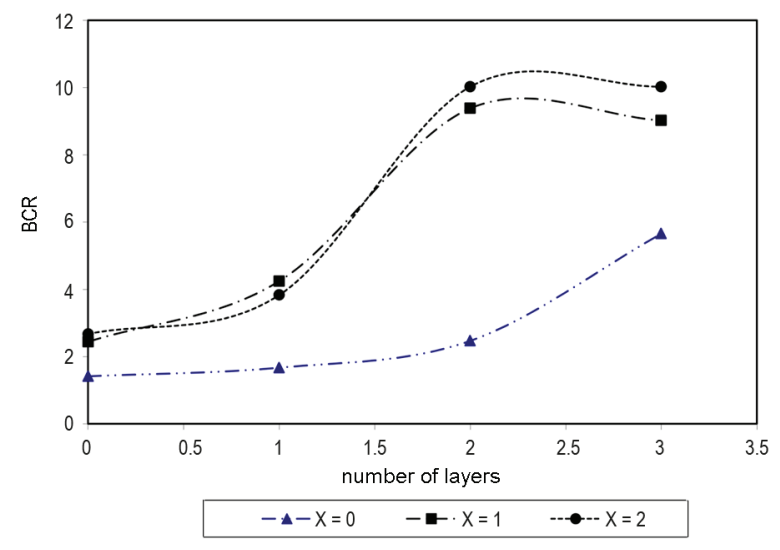

(b)

Fig. 7. Effect of the number of geotextile layers $\left(D_{r}=70 \%\right)$ : (a) $\mathrm{P}-\mathrm{S}$ curves and (b) $\mathrm{BCR}$

These studies demonstrated that after the inclusion of a critical number of geogrid layers, the BCR becomes constant.

\subsection{Effect of the edge distance of the footing on BCR}

Tests were conducted for the footing on reinforced and unreinforced $2 \mathrm{H}$ : $1 \mathrm{~V}$ slope with three different edge distances corresponding to $\mathrm{X} / \mathrm{B}=0,1,2$. The ratio of the reinforcement embedment depth to the footing width was kept constant at $\mathrm{d} / \mathrm{B}=0.5$, as determined from the earlier series of tests. For both reinforced and unreinforced slopes, the ultimate bearing capacity increases with increasing edge distance (Fig. 8a). At an edge distance of 2B, the ultimate bearing capacity of a footing on a sloping ground approaches that of a footing on a level surface in both reinforced and unreinforced cases. Furthermore, the ultimate bearing capacity of a footing on a reinforced slope is considerably higher than that of a footing on an unreinforced slope at any given edge distance (Fig. 8a). These results reflect the beneficial effect of reinforcement in the improvement of the bearing capacity of footings on slopes. The bearing capacity of strip footing on an unreinforced sandy slope increases with increasing $\mathrm{X} / \mathrm{B}$ before stabilizing at approximately $\mathrm{X} / \mathrm{B}=2$. The same trend was observed as the relative density of sand increased (Fig. 8b). Yoo (2001) indicated that the stress field underneath the footing is not symmetrical to the center of the footing. The stress field 


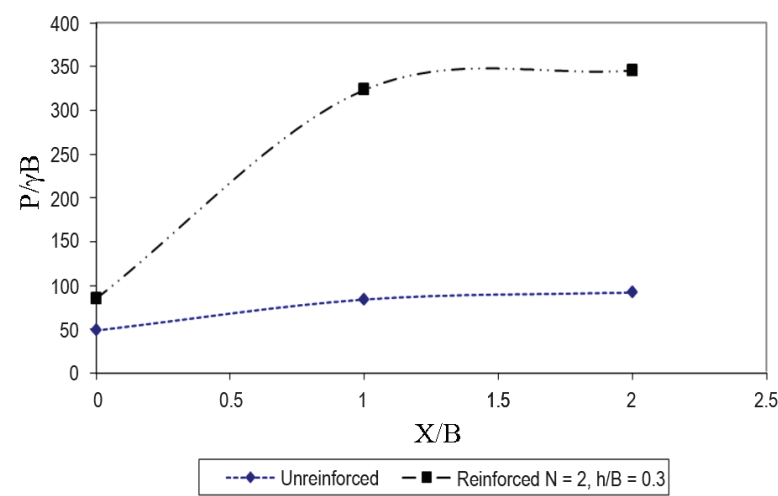

(a)

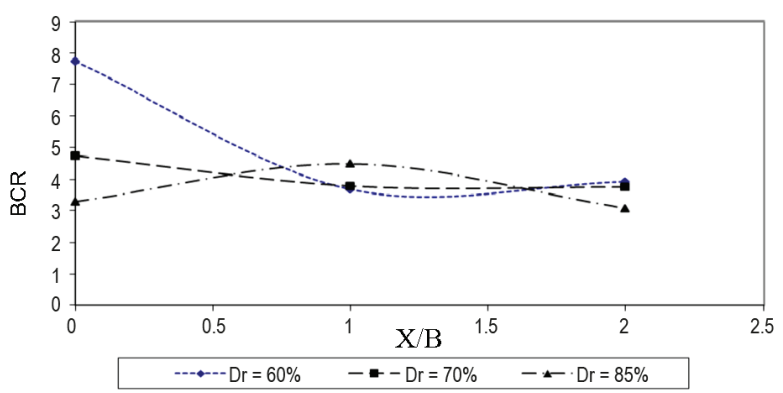

(b)

Fig. 8. Variations of: (a) $\mathrm{P} / \gamma \mathrm{B}$ with edge distance and (b) $\mathrm{BCR}$ with edge distance

was found to be symmetrical under axial concentric applied loads, and the ground surface extends to greater distances (i.e. higher than $5 \mathrm{~B}$ ) on both sides of the footing.

\subsection{Effect of the embedment ratio of double layers on BCR}

Tests were conducted on the model footing at the slope crest of the sand slope. The $\mathrm{P} / \gamma \mathrm{B}-\mathrm{S} / \mathrm{B}$ relationships of the strip footing on the double-reinforced slope were gathered and plotted (Fig. 3). The BCR varied from 1.09 to 7.73 . The maximum load occurred at $\mathrm{d} / \mathrm{B}=0.5$ and $\mathrm{H}_{\mathrm{r}} / \mathrm{B}=0.8$ with the vertical spacing ratio equal to 0.3 . To study the effect of the depth of the lower layer on footing-soil response, the embedment ratio of the upper layer $\mathrm{d} / \mathrm{B}$ was kept at 0.5 and the depth of the lower layer $\mathrm{H}_{\mathrm{r}} / \mathrm{B}$ changed to $0.8,1.0$, and 1.5. The most effective depth of the lower reinforcing layer is $\mathrm{H}_{\mathrm{r}} / \mathrm{B}=0.8$. When $\mathrm{H}_{\mathrm{r}} / \mathrm{B}=1.0$ and 1.5, the attained loads were very close to each other.

The effects of the location of the lower reinforcing layer were also examined. The most beneficial situation occurs when $\mathrm{h} / \mathrm{B}$ varies from 0.3 to 0.5 . In the plot of the $\mathrm{BCR}$ versus $\mathrm{H}_{\mathrm{r}} / \mathrm{B}$ for the studied cases (Fig. 9), the maximum $B C R$ was attained at $h / B=0.3$ if $X / B=0$ or 1 and at $\mathrm{h} / \mathrm{B}=0.5$ if $\mathrm{X} / \mathrm{B}=2$. These results are consistent with those of Lee and Manjunath (2000), Yoo (2001), and El Sawwaf $(2005,2007)$.

Table 4 presents comparisons between the BCRs of double-reinforced sand slope soil $\left(\mathrm{BCR}_{\mathrm{d}}\right)$ and those of single-reinforced sand slope soil $\left(\mathrm{BCR}_{\mathrm{S}}\right)$. The $\mathrm{BCR}_{\mathrm{s}}$ was presented by Abdrabbo et al. (2008). The $\mathrm{BCR}_{\mathrm{d}}$ cannot

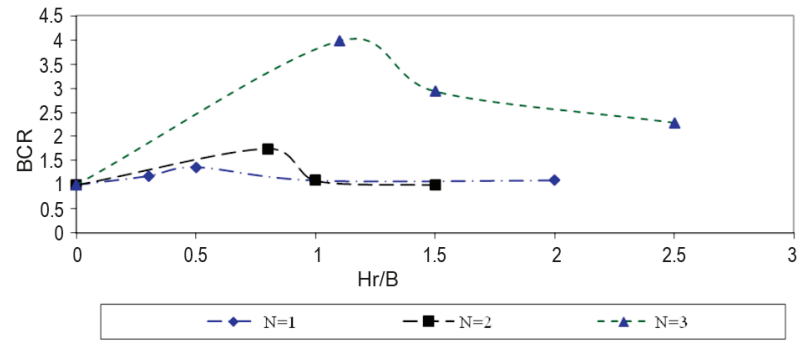

(a) $\mathrm{X} / \mathrm{B}=0$
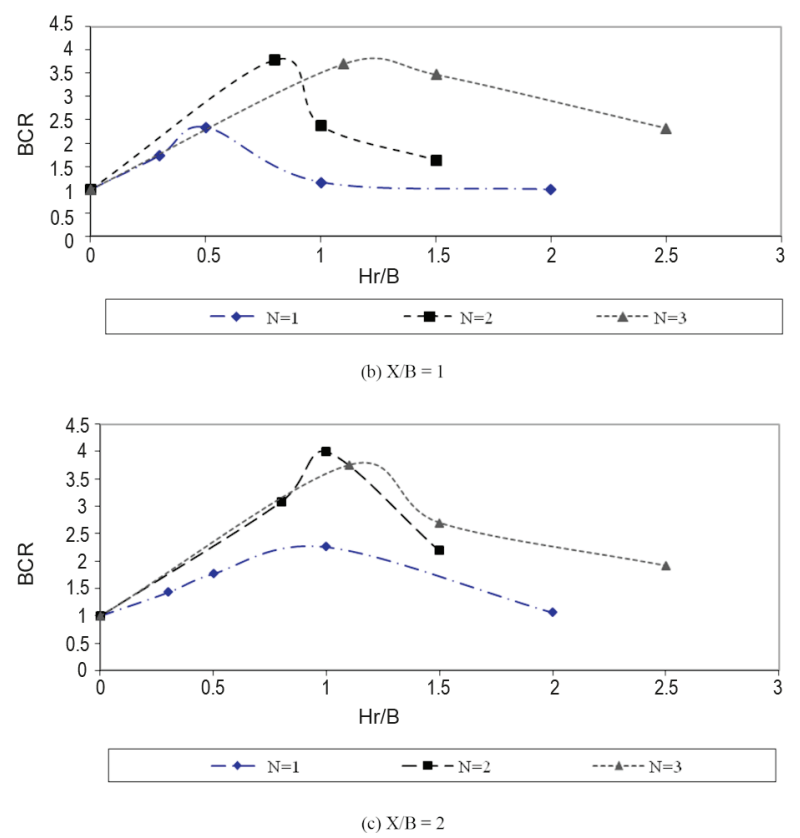

Fig. 9. BCR versus depth ratio of the lower reinforced layer: (a) $\mathrm{X} / \mathrm{B}=0$, (b) $\mathrm{X} / \mathrm{B}=1$, and (c) $\mathrm{X} / \mathrm{B}=2$

be summed directly from the $\mathrm{BCR}_{\mathrm{s}}$, but can be expressed in terms of the latter:

$$
B C R_{d}=Z \sum_{i=1}^{2} B C R_{S}
$$

where $Z$ is a parameter based on the depth ratios of the upper and lower reinforcing layers (Figs 10a and 10b). For example, Test (1) has the following values: $D_{r}=$ $85 \%, d_{1}=0.5 \mathrm{~B}$ (depth ratios of the upper layer); $H_{r}=$ $0.8 \mathrm{~B}$ (depth ratios of the lower layer); vertical spacing between the double layers $=0.3 \mathrm{~B} ; \mathrm{BCR}_{\mathrm{d}}=3.13$; summation $\mathrm{BCR}_{\mathrm{s}}$ at a depth ratio of $0.5 \mathrm{~B}$ and $\mathrm{BCR}_{\mathrm{S}}$ at a depth ratio of $0.8 \mathrm{~B}=3.831$; and $Z=\left(\mathrm{BCR}_{1}+\mathrm{BCR}_{2}\right) /$ $\left(\mathrm{BCR}_{\mathrm{d}}\right)=0.817019$. The obtained values of $Z$ decreases with the increasing depth ratios of the upper and lower reinforcing layers. The values of $Z$ can be obtained from Figures 10a or 10b. Meanwhile, the group effects of the double reinforcing layers at depths $d_{1}$ and $H_{r}$ will be larger than the sum of the effects of the single reinforcing layer at depth $d_{1}$ and $H_{r}$, as long as $d_{1}$ is less than $0.3 \mathrm{~B}$ and $H_{r}$ less is than $0.3 \mathrm{~B}$ when $D_{r}=60 \%$ as well as $d_{1}$ is less than $B$ when $D_{r}=70 \%$. For the higher values of $d_{1}$ and $H_{r}$, the group effects of the double reinforcing layers are less than the summation effects of the single 
Table 4. Comparison between values of the BCR

\begin{tabular}{|c|c|c|c|c|c|c|}
\hline Test & $D_{r} \%$ & $d_{1} / \mathrm{B}$ & $H_{r} / \mathrm{B}$ & $\mathrm{BCR}_{\mathrm{d}}$ & $\mathrm{BCR}_{1}+\mathrm{BCR}_{2}$ & $Z$ \\
\hline 1 & $85 \%$ & 0.5 & 0.8 & 3.13 & 3.831 & 0.817019 \\
\hline 2 & $85 \%$ & 0.5 & 1 & 3.7 & 4.342 & 0.852142 \\
\hline 3 & $85 \%$ & 0.5 & 1.5 & 2.4 & 3.871 & 0.619995 \\
\hline 4 & $85 \%$ & 0.5 & 2.5 & 2.17 & 3.2335 & 0.671099 \\
\hline 5 & $70 \%$ & 0.5 & 0.8 & 1.745 & 2.54 & 0.687008 \\
\hline 6 & $70 \%$ & 0.5 & 1 & 1.09 & 2.72 & 0.400735 \\
\hline 7 & $70 \%$ & 0.5 & 1.5 & 1 & 2.45 & 0.408163 \\
\hline 8 & $60 \%$ & 0.5 & 0.8 & 7.73 & 5.25 & 1.472381 \\
\hline 9 & $60 \%$ & 0.5 & 1 & 5 & 6 & 0.833333 \\
\hline 10 & $60 \%$ & 0.5 & 1.5 & 2.4 & 5.5 & 0.436364 \\
\hline 11 & $60 \%$ & 0.3 & 0.6 & 6.2 & 5.25 & 1.180952 \\
\hline 12 & $60 \%$ & 0.5 & 0.8 & 7.73 & 5.9 & 1.310169 \\
\hline 13 & $60 \%$ & 1 & 1.3 & 3.4 & 4.5 & 0.755556 \\
\hline 14 & $70 \%$ & 0.3 & 1 & 5 & 4.75 & 1.052632 \\
\hline 15 & $70 \%$ & 0.5 & 1 & 5 & 5.5 & 0.909091 \\
\hline 16 & $70 \%$ & 1 & 1.5 & 4.7 & 4.4 & 1.068182 \\
\hline 17 & $85 \%$ & 0.3 & 0.6 & 2.6 & 3.86 & 0.673575 \\
\hline 18 & $85 \%$ & 0.5 & 0.8 & 3.13 & 4.071 & 0.768853 \\
\hline 19 & $85 \%$ & 1 & 1.3 & 2.8 & 3.2 & 0.875 \\
\hline
\end{tabular}

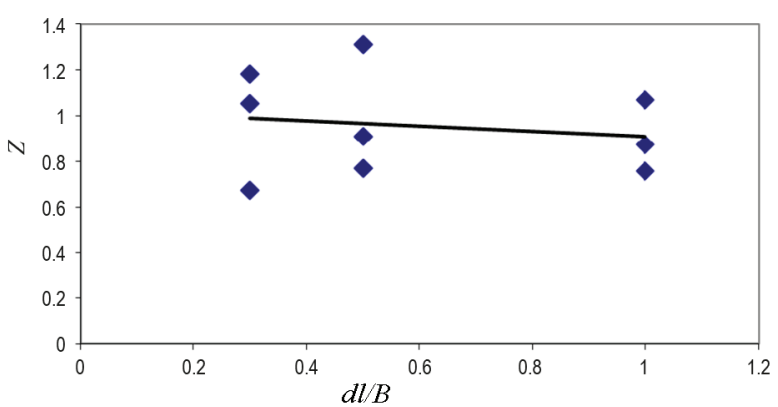

(a)

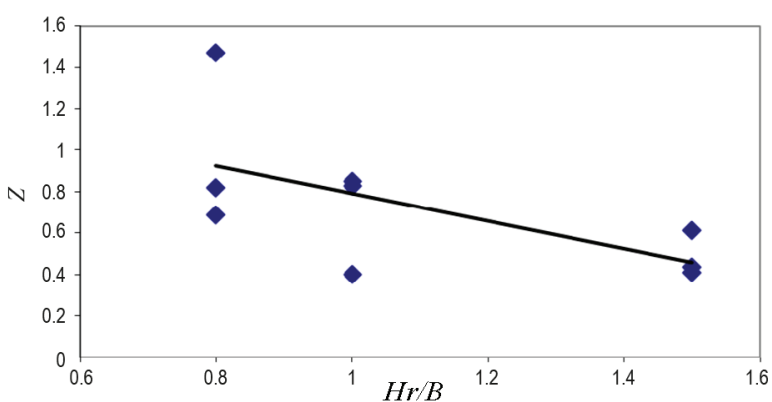

(b)

Fig. 10. Relationship between $Z$ placement and depth ratio (a) and relationship between $Z$ placement and height ratio (b)

layers. This response of the slope soil-footing system is attributed to the confinement of the sand underneath the footing. This confinement depends on the depth of the upper reinforcing layer, the spacing between the two layers, the relative density of the soil, and the reinforcement material.

\section{Conclusions}

The use of geotextiles is effective in the improvement of the bearing capacity of sand:

1) The BCR varies from 1.06 to 3.0 for singlereinforced soil.

2) The BCR increases to a value between 1.09 and 7.73 for double-reinforced slope and to 8.00 for triple reinforced slope.

3) The most effective vertical spacing between reinforcing layers is $0.3 \mathrm{~B}$ for double and triple reinforced slopes.

4) The effect of reinforcement on the bearing capacity of sand is more pronounced in soils with lower relative density than those with higher relative density. The optimum number of reinforcements is two.

5) The increase in the degree of bearing capacity depends not only on the geotextile layout but also on the footing location with respect to the slope face.

6) The $B C R_{d}$ can be expressed in terms of the $B C R_{s}$ as presented in the following:

$$
B C R_{d}=Z \sum_{i=1}^{2} B C R_{S} .
$$

$Z$ decreases with the increasing depth ratios of the upper and lower reinforcing layers.

\section{References}

Adams, M. T.; Collin, J. G. 1997. Large footing load tests on geosynthetic reinforced soil foundations, Journal of Geotechnical Engineering ASCE 123(1): 66-72.

http://dx.doi.org/10.1061/(ASCE)1090-0241(1997)123:1(66) 
Alamshahi, S.; Hataf, N. 2009. Bearing capacity of strip footings on sand slopes reinforced with geogrid and gridanchor, Geotextile and Geomembranes 27(3): 217-226. http://dx.doi.org/10.1016/j.geotexmem.2008.11.011

Abdrabbo, F. M.; Gaaver, K. E.; Omar, E. A. 2008. Behavior of strip footings on reinforced and unreinforced sand slope, GeoCongress 2008, ASCE, 25-32.

Boushehrian, J. H.; Hataf, N. 2003. 241 Experimental and numerical investigation of the bearing capacity of model circular and ring footings on reinforced sand, Geotextiles and Geomembranes 21(4): 241-256. http://dx.doi.org/10.1016/S0266-1144(03)00029-3

Choudhary, A. K.; Jha, J. N.; Gill, K. S. 2010. Laboratory investigation of bearing capacity behaviour of strip footing on reinforced flyash slope, Geotextiles and Geomembranes 28(4): 393-402.

http://dx.doi.org/10.1016/j.geotexmem.2009.09.007

Dash, S.; Sireesh, S.; Sitharam, T. 2003. Model studies on circular footing supported on geocell reinforced sand underlain by soft clay, Geotextiles and Geomembranes 21(4): 197-219. http://dx.doi.org/10.1016/S0266-1144(03)00017-7

Das, B. M.; Omar, M. T. 1994. The effects of foundation width on model tests for the bearing capacity of sand with geogrid reinforcement, Geotechnical and Geological Engineering 12: 133-141. http://dx.doi.org/10.1007/BF00429771

El Sawwaf, M. 2005. Strip footing behavior on pile and sheet pile stabilized sand slope, Journal of Geotechnology and Geoenvironmental Engineering 131(6): 705-715.

http://dx.doi.org/10.1061/(ASCE)1090-0241(2005)131:6(705)

El Sawwaf, M. 2007. Behavior of strip footing on geogridreinforced sand over a soft clay slope, Geotextile and Geomembranes 25(1): 50-60. http://dx.doi.org/10.1016/j.geotexmem.2006.06.001

El Sawwaf, M.; Nazir, A. K. 2010. Behavior of repeatedly loaded rectangular footings resting on reinforced sand, Alexandria Engineering Journal 49(12): 349-356. http://dx.doi.org/10.1016/j.aej.2010.07.002

El Sawwaf, M.; Nazir, A. K. 2011. Cyclic settlement behavior of strip footings resting on reinforced layered sand slope, Journal of Advanced Research 3(4): 315-324. http://dx.doi.org/10.1016/j.jare.2011.10.002

Fragaszy, R. J.; Lawton, E. 1984. Bearing capacity of reinforced sand subgrades, Journal of Geotechnical Engineering ASCE 110(GT10): 1500-1511.

http://dx.doi.org/10.1061/(ASCE)0733-9410(1984)110:10(1500)
Huang, C.; Tatsuoka, F.; Sato, Y. 1994. Failure mechanisms of reinforced sand slopes loaded with a footing, Soils and Foundations 24(2): 27-40. http://dx.doi.org/10.3208/sandf1972.34.2 27

Jahanandish, M.; Keshavarz, A. 2005. Seismic bearing capacity of foundations on reinforced soil slopes, Geotextiles and Geomembranes 23(1): 1-25. http://dx.doi.org/10.1016/j.geotexmem.2004.09.001

Lee, K. M.; Manjunath, V. R. 2000. Experimental and numerical studies of geosynthetic - reinforced sand slopes loaded with a footing, Canadian Geotechnical Journal 37(4): 828-842. http://dx.doi.org/10.1139/t00-016

Manjunath, V. R.; Dewaikar, D. M. 1994. An experimental study of strip footing on geosynthetic reinforced slopes, in Proceedings of Indian Geotechnical Conference, 1994, vol. 1, 271-274.

Milligan, G. W. E.; Fannin, R. J.; Farrar, D. F. 1986. Model and full-scale tests of granular layers reinforced with a geogrid, in Proceedings of the $3^{\text {rd }}$ International Conference on Geotextiles, 7-11 April 1986, Vienna, Austria, 61-66.

Mittal, S.; Shah, M. Y.; Verma, N. K. 2009. Experimental study of footing on reinforced earth slope, International Journal of Geotechnical Engineering 3(2): 251-260. http://dx.doi.org/10.3328/IJGE.2009.03.02.251-260

Moghaddas Tafreshi, S. N.; Dawson, A. R. 2010. Behavior of footings on reinforced sand subjected to repeated loading comparing use of 3D and planar geotextile, Geotextiles and Geomembranes 28(5): 434-447.

http://dx.doi.org/10.1016/j.geotexmem.2009.12.007

Omar, M.; Das, B.; Puri, V.; Yen, S. 1993. Ultimate bearing capacity of shallow foundations on sand with geogrid reinforcement, Canadian Geotechnical Journal 30(3): 545-549. http://dx.doi.org/10.1139/t93-046

Patra, C. R.; Das, B. M.; Atalar, C. 2005. Bearing capacity of embedded strip foundation on geogrid-reinforced sand, Geotextiles and Geomembranes 23(5): 454-462. http://dx.doi.org/10.1016/j.geotexmem.2005.02.001

Patra, C. R.; Das, B. M.; Bhoi, M.; Shin, E. C. 2006. Eccentrically loaded strip foundation on geogrid-reinforced sand, Geotextiles and Geomembranes 24(4): 254-259. http://dx.doi.org/10.1016/j.geotexmem.2005.12.001

Selvadurai, A. P. S.; Gnanendran, C. T. 1989. An experimental study of a footing located on a sloped fill: influence of a soil reinforcement layer, Canadian Geotechnical Journal 26(3): 467-473. http://dx.doi.org/10.1139/t89-059

Yoo, C. 2001. Laboratory investigation of bearing capacity behaviour of strip footing on geogrid - reinforced sand slope, Geotextiles and Geomembranes 19(5): 279-298. http://dx.doi.org/10.1016/S0266-1144(01)00009-7

Enas Belqasem ALTALHE. Is PhD candidate, Department of Civil and Structural Engineering, Universiti Kebangsaan Malaysia. She obtained her MSc in Geotechnical Engineering from Faculty of Engineering, Alexandria University, Egypt in 2006. She is a lecturer at Omar Al-Mukhtar University, Libya. Her main research interest is geotechnical and geoenvironmental engineering, particularly on the applications of geosynthetics in soil remediation and improvement, numerical modeling and constitutive relations.

Mohd Raihan TAHA. Dr, is a Professor and Head of the Department of Civil and Structural Engineering, Universiti Kebangsaan Malaysia. He obtained his PhD in Civil Engineering from Louisiana State University, USA in 1996. He is a Graduate member of The Institution of Engineers, Malaysia. He was the recipient of the prestigious Royal Society United Kingdom Fellowship for 2005. In 2012 he was awarded the Telford Premium Prize from The Institution of Civil Engineers, United Kingdom. He has published well over 300 articles in journals and conference proceedings. His main research interest is geotechnical and geoenvironmental engineering, particularly on the applications of nanomaterial's in soil remediation and improvement, numerical modeling and constitutive relations.

Fathi Mohamed ABDRABBO. Dr, is a Professor of Soil Mechanics and Foundation Engineering, Alexandria University, Egypt. He obtained his $\mathrm{PhD}$ in Geotechnical Engineering from Southampton University, UK in 1976. He is Member of the American Society of Civil Engineers (ASCE), geotechnical institute, USA, Egyptian Engineers Syndicate, International society of soil mechanics and foundation engineering, Egyptian scientific committee for university professor's nomination, Egyptian committee for soil mechanics and foundation national code and Member of Egyptian committee for road construction national code. His research interests include geotechnical engineering, particularly the in soil improvement. 